\title{
EROSION OF ACCESS TO ABORTION IN THE UNITED STATES: LESSONS FOR AUSTRALIA
}

\author{
Rebecca Dean ${ }^{*}$
}

[Since the legalisation of abortion in the United States (US) in 1973, access to abortion has been restricted and under attack from multiple fronts. From a pro-choice perspective, this article analyses the way women's access to abortion has been eroded in the US. This article considers: Roe $v$ Wade and chronicles the subsequent cases decided by the US Supreme Court which have gradually dismantled its holding; the various US state and federal legislative restrictions on abortion and their impact on access to abortion; the new composition of the US Supreme Court and the consequences for women's access to legal abortion; and a brief overview of abortion in Australia. Awareness of anti-choice tactics used to restrict access to abortion in the US may prevent a similar erosion of abortion rights in Australia.].

Each year approximately 210 million women become pregnant. ${ }^{1}$ An estimated 80 million of these pregnancies are unplanned. Forty-six million abortions ${ }^{2}$ are carried out annually around the globe, 27 million are terminated legally,

\footnotetext{
* LLB Hons La Trobe University, BA/BCom Monash University, Articled Clerk at Clayton Utz. The author wishes to thank Dr Susie Allanson for her support, guidance and insight, Judith Gutman for her encouragement and suggestions, and the Deakin Law Review referee.

${ }^{1}$ Ina K Warriner and Iqbal H Shah (eds), Preventing Unsafe Abortion and Its Consequences: Priorities for Research and Action (2006).

2 Abortion is defined as "the removal of a human foetus [or embryo] before viability": The Macquarie Dictionary: Federation Edition (2001).
} 
and 19 million are performed illegally. ${ }^{3}$ Where abortion is legal and accessible, abortion procedures will generally be safe because they are performed by trained practitioners in a regulated medical setting. ${ }^{4}$

Where abortions are illegal, they are also generally unsafe. ${ }^{5}$ Annually, an estimated 68,000 women die and 5.3 million suffer temporary or permanent disability as a result of 20 million unsafe abortions. ${ }^{6}$ Women will continue to have unplanned pregnancies they seek to abort because, among other factors, contraception is not one hundred percent effective, and rape and domestic violence are prevalent around the world. Safe abortion is necessary to prevent pregnancy related deaths and injuries resulting from unsafe abortions. ${ }^{7}$ Risks associated with unsafe abortion impact adversely on pregnant women, their families and society. In countries where abortion is illegal, or safe abortion is inaccessible, obstetrics beds are generally filled with women suffering from complications of unsafe abortions. ${ }^{8}$ Women seek abortions even where they are illegal or unsafe. ${ }^{9}$

In the US in 2003, an estimated 1,287,000 abortions were performed annually. ${ }^{10}$ Following the 1973 legalisation of abortion in the US in Roe $v$ Wade $^{11}$, the American anti-choice ${ }^{12}$ movement has employed a coordinated and well-financed campaign to chip away at access to abortion. Far less

\footnotetext{
${ }^{3}$ Elisabeth Ahman and Iqbal Shah (P Butler is the editor), Unsafe Abortion: Global and regional estimates of the incidence of unsafe abortion and associated mortality in 2000 ( $4^{\text {th }}$ ed, 2004).

${ }^{4}$ Warriner and Shah, above $\mathrm{n} 1$.

${ }^{5}$ Ahman and Shah, above $\mathrm{n} 3$.

${ }^{6}$ Unsafe abortion is defined as "a procedure for terminating an unwanted pregnancy either by persons lacking the necessary skills or in an environment lacking the minimal medical standards, or both": Warriner and Shah, above $\mathrm{n} 1$.

${ }^{7}$ World Health Organisation, Safe Abortion: Technical and Policy Guidance for Health Systems, (2003) World Health Organisation

$<$ http://www.who.int/reproductive-health/publications/safe_abortion/index.html $>$ at 10 September 2006.

${ }^{8}$ Warriner and Shah, above $\mathrm{n} 1$.

${ }^{9}$ Ibid.

${ }^{10}$ Lawrence B Finer and Stanley K Henshaw, Estimates of U.S. Abortion Incidence, 2001-2003 (2006).

${ }^{11}$ Roe v Wade, 410 US 113 (1973).

12 The term "anti-choice" refers to abortion opponents such as Right to Life and Pro Life groups, who believe abortion should be illegal, and once pregnant, women should have no choice but to continue their pregnancy to term. The term "pro-choice" is used in the article to describe people who believe women should have access to legal abortion services and the right to choose to have an abortion.
} 
visible than the violent attacks on abortion clinics and personnel in the 1980s, the anti-choice movement has undertaken a long-term campaign which has gradually eroded women's access to abortion to the extent that elective abortion is inaccessible for some US women. The anti-choice movement's tactics have been insidious, intelligent and well resourced, infiltrating all three branches of government and the Supreme Court. Anti-choice policy-makers and supporters have utilised a "divide-and-conquer" tactic $^{13}$ focused on restricting access to abortion by dividing women into separate groups ${ }^{14} \cdot{ }^{15}$

US Supreme Court decisions have eroded women's constitutional right to abortion ${ }^{16}$ and provided scope for state legislatures to restrict access to abortion ${ }^{17} .{ }^{18}$ The Federal government has implemented numerous domestic and foreign policies curtailing funding to abortion and reproductive services. ${ }^{19}$ US delegates have consistently expressed their disdain for reproductive rights at Human Rights conventions. State legislatures have obstructed women's access to abortion services by imposing restrictive regulations on the provision of abortion services and on abortion providers. ${ }^{20}$ The Supreme Court's new composition could spell the end to abortion rights in the US by overturning Roe. ${ }^{21}$ If Roe falls, abortion will immediately, or imminently, become illegal for a majority of women living in the US. ${ }^{22}$

\footnotetext{
${ }^{13}$ Tactics utilised by anti-choice groups to decrease women's access to abortion in the US is explored in greater detail in Parts 2 and 3 of this article.

${ }^{14}$ These groups include: low-income women, young women and impoverished foreign women

${ }^{15}$ Julia L Ernst, Laura Katzive and Erica Smock, 'Symposium: The Legacy of Roe: The Constitution, Reproductive Rights, and Feminism: The Global Pattern of U.S. Initiatives Curtailing Women's Reproductive Rights: A Perspective On The Increasingly Anti-Choice Mosaic' (2004) 6(4) University of Pennsylvania Journal of Constitutional Law 752.

${ }^{16}$ Roe $v$ Wade established that a woman's right to choose to terminate her pregnancy is protected by a person's fundamental right to privacy derived from the right to personal liberty embodied in the Due Process Clause of the fourteenth amendment of the US Constitution.

${ }^{17}$ State legislatures restriction of access to abortion is analysed in Part 3 of this article.

${ }^{18}$ Kerry A Petersen, Abortion Regimes (1993).

${ }^{19}$ US foreign and domestic policies restricting access to abortion are analysed in Part 4 of this article.

${ }^{20}$ State regulations are analysed in Part 3 of this article.

${ }^{21}$ The Supreme Court's composition is considered in Part 4 of this article.

${ }^{22}$ The impact of the fall of Roe is analysed in Part 4.2 of this article.
} 
From a pro-choice perspective, this article attempts to address two apparent gaps in the abortion literature: (i) synthesising US abortion access issues usually reported in relative isolation from one another; and (ii) briefly relating this synthesis to the abortion situation in Australia to provide information and signposts to prevent a similar erosion of abortion rights in Australia. Part 1 of this article considers Roe $v$ Wade and chronicles the subsequent cases decided by the US Supreme Court which have gradually dismantled its holding. Part 2 scrutinises the various federal restrictions imposed on abortion. Part 3 examines the various state regulations limiting access to abortion. Part 4 explores the new composition of the US Supreme Court and what the fall of Roe could ultimately mean for women's access to legal abortion. Part 5 briefly considers abortion in Australia.

\section{THE EROSION OF ROE V WADE: ABORTION DECISIONS IN THE US SUPREME COURT SINCE ROE}

In 1973, in Roe, the US Supreme Court held that American women had a constitutional right to abortion. Pro-choice advocates celebrated the liberation of women's reproductive rights and right to bodily autonomy and determination. Suddenly American women had the right to determine if, when and how many children they would have. Women in the US had the potential to participate in society in ways they were never able to before.

A backlash followed legalisation of abortion in the US. Anti-choice groups began their fight to deny women access to abortion. For 16 years the Supreme Court stood by its decision to recognize a woman's constitutional right to abortion. However, after 1989, the Supreme Court gradually began to chip away at Roe. Today, very little of Roe's original holding remains. Although the core principal, a woman's constitutional right to abortion remains, it teeters on the brink of collapse. Subsequent cases $^{23}$ have stripped back a woman's right to abortion to a point where the right is almost non-existent because access is almost non-existent. Outlined below is an analysis of the Supreme Court cases which have shaped, and gradually eroded, women's access to abortion.

\footnotetext{
${ }^{23}$ For example: Webster v Reproductive Health Services, 492 US 490 (1989) at 501; Planned Parenthood of Southeastern Pennsylvania v Casey, 505 US 833 (1992); Stenberg v Cahart, 530 US 914 (2000); Ayotte v New Hampshire, 126 S Ct 961 (2005) outlined below.
} 


\section{A Roe $v$ Wade (1973)}

The landmark abortion case, Roe, was one of many abortion cases in line to the Supreme Court in 1972. Roe challenged the constitutionality of a Texan statute, similar to those in thirty other American states, which made abortion a felony except where necessary to save the life of the pregnant woman. ${ }^{24}$ The case was a class action suit brought to determine the rights of 'Jane Roe'25, and all women in a similar situation.

Prior to Roe the Supreme Court had established that the Constitution protected a fundamental right to privacy ${ }^{26}$ which includes matters of family life and marriage, including contraception. ${ }^{27}$ In a 7-2 majority decision in Roe, the Supreme Court expanded the constitutional right of privacy to include a woman's right to choose to have an abortion. The court held that a woman's right to choose to terminate her pregnancy is protected by a person's fundamental right to privacy derived from the right to personal liberty embodied in the Due Process Clause of the fourteenth amendment of the US Constitution. ${ }^{28}$ The court established that within the meaning of the fourteenth amendment, an unborn foetus or embryo is not a 'person'. ${ }^{29}$ This decision had the effect of striking down numerous restrictive state abortion laws ${ }^{30}$ and providing women with a constitutional right to abortion. ${ }^{31}$

However, a woman's right to abortion was not completely without state intervention. In the US, privacy is a fundamental right that can only be restricted where the state has a compelling interest. ${ }^{32}$ The Court implemented a trimester framework for regulating abortion which meant that a woman's autonomy to terminate a pregnancy is greatest in the first trimester and least in the third. This framework was premised on the Court's contention that a compelling state interest in potential life is limited to the point when viability

\footnotetext{
${ }^{24}$ Texas Penal Code, Arts 1191-1194, 1196, (1857).

25 'Jane Roe' was a pseudonym for an unmarried pregnant woman who could not obtain an abortion under the Texan statute.

${ }^{26}$ Griswold v Connecticut, 381 US 479 (1965) at 494-495; Eisenstadt v Baird, 405 US 438 (1972).

${ }^{27}$ Roe $v$ Wade, 410 US 113 (1973).

${ }^{28}$ Ibid.

${ }^{29}$ Ibid at 158.

${ }^{30}$ See Part 4 of this article for greater detail regarding state laws on abortion.

${ }^{31}$ Eileen L McDonagh, 'My body, my consent: securing the constitutional right to abortion funding (symposium on abortion)' (1999) 62(3) Albany Law Review 1057.

${ }^{32}$ Roe v Wade, 410 US 113 (1973) at 154.
} 
occurs, the third trimester. ${ }^{33}$ In the first trimester of pregnancy the state cannot regulate a woman's decision to terminate her pregnancy. In the second trimester the state can regulate in ways 'reasonably related' to protecting maternal health. In the third trimester a woman is only entitled to an abortion where it is necessary to preserve her life or health. ${ }^{34}$

\section{B Doe v Bolton (1973)}

Doe $v$ Bolton $^{35}$ was decided on the same day as Roe and intended to be read as Roe's companion case. Roe stated that restrictions on second and third trimester abortions must contain an exception for the preservation of the life and health of the pregnant woman. ${ }^{36}$ Doe provided a definition of woman's health which included all factors relevant to the well being of the patient including physical, emotional, psychological, familial, and the woman's age. ${ }^{37}$

\section{Webster v Reproductive Health Services}

The 1989 case of Webster $^{38}$ was the first case to threaten Roe's legalisation of abortion. The Supreme Court considered a 1986 Missouri statute ${ }^{39}$ which declared in its preamble that life begins at conception, that all "unborn children have protectable interests in life, health, and well-being" 40 and that Missouri laws should be "interpreted to provide unborn children with the rights enjoyed by other persons." ${ }^{41}$ The statute required physicians prior to performing an abortion on pregnancies of twenty weeks or more to "perform such medical examinations and tests as are necessary to make a finding of [the foetus'] gestational age, weight, lung maturity to assess viability." 42 The statute also prohibited "the use of state employees and facilities to perform abortions except to save the mother's life...[or] public funds, employees or

\footnotetext{
${ }^{33}$ Ibid at 163 .

${ }^{34}$ Ibid at $164-165$.

${ }^{35}$ Doe $v$ Bolton, 410 US 179 (1973).

${ }^{36}$ Roe $v$ Wade, 410 US 113 (1973) at 164.

${ }^{37}$ Doe v Bolton, 410 US 179 (1973) at 192.

${ }^{38}$ Webster v Reproductive Health Services, 492 US 490 (1989) at 501.

${ }^{39}$ NEB REV STAT §188.205 (1986).

${ }^{40}$ Ibid at 491.

${ }^{41}$ Ibid at 491 .

${ }^{42}$ Ibid at 491 .
} 
facilities from 'encouraging or counseling' abortions not necessary to save the mother's life."

The Court upheld the statute's preamble, finding that it simply provided protection to embryos and foetuses as 'unborn children' in probate and tort law. ${ }^{44}$ In assessing the statute's provisions requiring tests regarding viability, the Court criticised the Roe trimester and viability doctrine. The Court held the provision permissible as it furthered the State's interest in protecting potential human life acknowledged in $R o e .^{45}$

Signalling the Supreme Court's willingness to overturn Roe, the Court upheld the Missouri statute in a 5-4 decision. Four justices voted to overturn Roe and four voted to reaffirm it. As Borgman (2004) suggests, "the plurality's deference to the state's interests signalled a significant retreat from Roe's strict scrutiny standard, the highest level of constitutional review." decision of Justice Sandra O'Connor articulated a new legal standard. O'Connor found the Missouri law was not an "undue burden" on a woman's right to choose, therefore the statute was constitutional. ${ }^{47}$ This new standard suggested that a woman's right to choose was no longer a fundamental constitutional right. For an abortion law to be unconstitutional, it had to represent a substantial obstacle to a woman accessing an abortion. In many ways this decision appeared to call for states to pass legislation banning abortion to test how far the law would allow them to erode women's access. ${ }^{48}$ Perhaps the statement most representative of the nature of the Supreme Court's holding, was Justice Blackmun's minority decision:

[F]or today, the women of this Nation still retain the liberty to control their destinies. But the signs are evident and very ominous, and a chill wind blows. ${ }^{49}$

\footnotetext{
${ }^{43}$ Ibid at 491.

${ }^{44}$ Ibid at 501 .

${ }^{45}$ Ibid at 520 .

${ }^{46}$ Caitlin E Borgmann, 'Winter Count: Taking Stock of Abortion Rights After Casey and Carhart' (2004) 31(3) Fordham Urban Law Journal 675, 676.

${ }^{47}$ Webster v Reproductive Health Services, 492 US 490 (1989) at 526.

${ }^{48}$ Centre For Reproductive Rights, Roe v Wade - Then and Now (January 2003)

Centre For Reproductive Rights

$<\mathrm{http}$ ///www.reproductiverights.org/crt_roe_jbroe.html $>$ at 20 July 2006.

${ }^{49}$ Webster v Reproductive Health Services, 492 US 490 (1989) at 560.
} 


\section{Planned Parenthood of Southern Pennsylvania $v$ Casey (1992)}

In many ways Casey $^{50}$ represented the culmination of Justice Blackmun's concerns in Webster. The issue before the Supreme Court in Casey was the review of four provisions in a Pennsylvania abortion law. ${ }^{51}$ The law contained the following restrictions on first trimester abortion, requiring:

1. Informed consent - women were to be given information regarding foetal development and the medical risks of abortion and childbirth;

2. A 24 hour waiting period;

3. Consent by at least one parent of a minor, with a judicial bypass option; and

4. Married women sign a statement that she had notified her husband of the procedure. ${ }^{52}$

In a 5-4 decision the court upheld all provisions referred to above except the husband notification provision. In deeming the spousal notification provision unconstitutional the justices acknowledged the danger and constraints domestic violence impose on individual women. ${ }^{53}$ They held such a provision would prevent a "significant number of women who fear for their safety and the safety of their children... from procuring an abortion as surely as if the Commonwealth had outlawed abortions in all cases." 54

The joint decision stated that Roe's 'essential holding', that is, a woman's constitutional right to abortion, was reaffirmed. Although Casey is known as upholding Roe, it substantially dismantled Roe's framework. ${ }^{55}$ Casey rejected Roe's trimester framework redefining Roe as comprising three parts:

1. "A recognition of a woman's right to choose an abortion before viability and to obtain it 'without undue interference' from the state;

${ }^{50}$ Planned Parenthood of Southeastern Pennsylvania v Casey, 505 US 833 (1992).

${ }_{51}^{51}$ Pennsylvania Abortion Control Act, § 3205, (1982).

${ }^{52}$ Planned Parenthood of Southeastern Pennsylvania v Casey, 505 US 833 (1992) at 834.

${ }^{53}$ Ibid at $893-894$.

${ }^{54}$ Ibid at 894.

${ }^{55}$ Chris Whitman, 'Looking Back on Planned Parenthood v Casey' (2002) 100(7)

Michigan Law Review 1980. 
2. A confirmation of the government's power to restrict abortions after foetal viability, provided such restrictions contain exceptions 'for pregnancies which endanger the woman's life or health; and

3. A recognition that the government has 'legitimate interests from the outset of the pregnancy in protecting the health of the woman and the life of the foetus'., 56

Casey advocated a distinction between pre and post viability abortions. Postviability abortions were subject to the same limitations as third trimester abortions under Roe. Utilising Justice O'Connor's legal standard from Webster, Casey affirmed that states could regulate pre-viability abortions and impose restrictions as long as they did not impose an 'undue burden' on a woman's right to choose abortion. Under this new standard, regulation of abortion would be invalid if it had the purpose or effect of placing "a substantial obstacle in the path of a woman seeking an abortion before the foetus attains viability." ${ }^{, 57}$ Perhaps in demonstration of its prioritization of the state's interest in foetal life, the Court also shifted the burden of proof regarding a compelling state interest for regulation from the state to the plaintiff or woman who must prove the regulation imposes an 'undue burden' on her right to choose. ${ }^{58}$

Casey made abortion rights more vulnerable by essentially giving state legislatures permission to test how far they could restrict abortion access. ${ }^{59}$ Legislatures were "given liberty to enact laws favoring childbirth, promoting 'foetal life', burdening access to abortion, and restricting abortion based on 'morality'... as long as the vaguely defined line of 'undue burden was not crossed." ${ }^{60}$ The Court summarised its new undue burden standard as promoting:

[T]he State's profound interest in potential life, throughout pregnancy the State may take measures to ensure that the woman's choice is informed, and measures designed to advance this interest will be valid as long as their purpose is to persuade

\footnotetext{
${ }^{56}$ Borgmann, above n 46, 277.

${ }^{57}$ Planned Parenthood of Southeastern Pennsylvania v Casey, 505 US 833 (1992) at 877.

${ }^{58}$ Mark Leighton, 'Fourth Annual Review of Gender and Sexuality Law:

Constitutional Law Chapter: Abortion' (2002) 4 (Fall) The Georgetown Journal of

Gender and the Law 47, 50.

${ }^{59}$ Borgmann, above $\mathrm{n} 46,675$.

${ }^{60}$ Ernst, Katzive and Smock, above n 15, 769.
} 
the woman to choose childbirth over abortion. These measures must not be an undue burden on the right. ${ }^{61}$

\section{E Stenberg v Carhart (2000)}

Thirty-one states tested the new 'undue burden' standard established in Casey by enacting abortion bans via 'partial birth abortion' legislation. ${ }^{62}$ 'Partial birth abortion' is a non-medical, intentionally emotive term. These laws purport to ban only specific abortion procedures used in late term abortions, however in reality they ban safe abortion procedures used as early as twelve weeks gestation. ${ }^{63}$ 'Partial Birth Abortion' refers to the 'dilation and evacuation' ('D\&E') and 'dilation and extraction' ('D\&X') abortion methods which account for approximately $0.17 \%$ of all abortions carried out in the US each year. ${ }^{64}$ The language used by the bans is intentionally broad and vague, encompassing numerous common and safe methods of abortion, thus threatening general access to abortion. ${ }^{65}$

In Stenberg", the Nebraskan statute at issue banned all 'partial birth abortions' except where the pregnant woman's life was at stake. In a 5-4 ruling the Supreme Court held the Nebraskan law unconstitutional for two reasons. First, any ban to a method of abortion must contain a health exception $^{67}$, no such exception was present in the statute. ${ }^{68}$ Second, the ban constituted an undue burden on a woman's right to choose abortion, because it prohibited several abortion methods, including the safest and most common method for performing second trimester, pre-viability abortions. ${ }^{69}$ This decision had the effect of declaring unconstitutional all similar laws enacted by other state legislatures.

${ }^{61}$ Planned Parenthood of Southeastern Pennsylvania v Casey, 505 US 833 (1992) at 878.

${ }^{62}$ Ernst, Katzive and Smock, above n 15.

${ }^{63}$ Ibid.

${ }^{64}$ Allisa Schecter, 'Choosing balance: Congressional powers and the Partial Birth Abortion Ban Act of 2003' (2005) 73 (March) Fordham Urban Law Journal 1987.

${ }^{65}$ Borgmann, above n 46, 675.

${ }^{66}$ Stenberg $v$ Cahart, 530 US 914 (2000).

67 "For the preservation of the... health of the mother": Planned Parenthood of Southeastern Pennsylvania v Casey, 505 US 833 (1992) at 879.

${ }^{68}$ Stenberg $v$ Cahart, 530 US 914 (2000).

69 Ibid. 
The 5-4 margin in Stenberg demonstrated the perilous nature of abortion rights in the US. With potential changes to the Court's composition due to old age and illness the possibility of Roe being overturned was very real.

\section{F $\quad$ Ayotte v New Hampshire (2005)}

Ayotte $^{70}$ concerned a challenge to a New Hampshire statute requiring that "no abortion shall be performed upon an unemancipated minor or upon a female for whom a guardian or conservator has been appointed... until at least 48 hours after written notice of the pending abortion has been delivered." "T1 $T$ The court was asked two questions. First, whether the law was unconstitutional because the parental notification statute did not provide a health exception. ${ }^{72}$ Second, the anti-choice side argued that the standard of review for abortion cases, "the undue burden" standard, should be changed so that even if a law was unconstitutional for some minors the law should remain on the books and exceptions be made on a case by case basis. ${ }^{73}$ This sort of change to the standard of review would severely restrict women's access to abortion. Essentially states could make abortion illegal and women would have to apply to the court on a case-by-case basis to argue for their right to have an abortion.

The Court's January 18, 2006 ruling, sidestepped the issue of whether the undue burden standard should be replaced. The Court instead decided Ayotte on the ground of remedy. ${ }^{74}$ The Court unanimously agreed that the lower Court had wrongfully struck down the New Hampshire abortion law. The Court held that although the legislation was unconstitutional without a health exception, nullifying the whole law was not the correct remedy. ${ }^{75}$ The Court returned the case to the Court of Appeals to decide a remedy which could correct the Act's constitutional flaw without invalidating it entirely. ${ }^{76}$

${ }^{70}$ Ayotte v New Hampshire, $126 \mathrm{~S} \mathrm{Ct} 961$ (2005).

${ }^{71}$ Parental Notification to Abortion Act, 10 NH REV STAT ANN $\S 132.24$ to 132.28, (2003).

${ }^{72}$ Ayotte v New Hampshire, $126 \mathrm{~S} \mathrm{Ct} 961$ (2005) at 963.

${ }^{73}$ FRONTLINE, Roe $v$ Wade and Beyond (2006) PBS

$<$ http://www.pbs.org/wgbh/pages/frontline/clinic/wars/cases.html\#ayotte $>$ at 20 July 2006.

${ }^{74}$ Nathaniel Law, 'Abortion: Supreme Court Avoids Disturbing Abortion Precedents By Ruling On Grounds of Remedy - Ayotte v Planned Parenthood of Northern New England' (2006) 34(2) Journal of Law, Medicine and Ethics 469, 470.

${ }_{76}^{7 y o t t e} v$ New Hampshire, 126 S Ct 961 (2005).

${ }^{76}$ Ibid. 


\section{G The Erosion of Roe}

As demonstrated by the US Supreme Court cases following Roe, Roe's holding has been severely curtailed. The Court is potentially only one case away from overturning Roe completely and, as a result of these Supreme Court decisions, Federal and State governments now have broader scope to obstruct women's access to abortion, and undermine reproductive rights in the US.

\section{US FEDERAL RESTRICTIONS ON ABORTION}

Since the legalisation of abortion in Roe, the Federal government has implemented numerous domestic and foreign initiatives restricting women's access to abortion. Some of these initiatives are canvassed below.

\section{A The Hyde Amendment (HA) - Harris v McRae}

The 1977 HA represented the first congressional challenge to abortion since Roe. ${ }^{77}$ The Amendment prohibited government funding of abortion through Medicaid $^{78}$ and other health, education and welfare appropriations, except where necessary to save the life of a pregnant woman. ${ }^{79}$ Although the amendment did not affect abortion's legality, it represented one of the first anti-choice tactics for destroying women's access - making abortion a financially prohibitive option for low-income women. Via subsequent amendments, HA now also applies to military personnel and their dependents, federal workers, women living on Native American reservations and women in federal prisons.

After a long battle, exceptions for rape and incest were included in HA in 1993. However, these were short lived. In 1995 Congress rescinded all but the life endangerment exception. ${ }^{80}$ The consequences of HA are illustrated by

${ }^{77}$ Claudine Holt, Abortion: A Woman's Right to Choose $<$ http://www.dsp.org.au/dsp.abortion.htm> at 15/7/2006.

${ }^{78}$ Medicaid is the US medical health insurance scheme.

${ }^{79}$ Kathryn Kolbert and Andrea Miller, 'Legal Strategies for Abortion Rights in the Twenty-First Century' in R Solinger (ed) Abortion Wars: A Half Century Of Struggle 1950-2000 (1998) 95.

${ }^{80}$ Marlene Gerber Fried, 'Abortion in the United State - Legal but Inaccessible' in R Solinger (ed) Abortion Wars: A Half Century of Struggle 1950 - 2000 (1998) 208. 
Fried's (1998) examples of women who were disqualified from abortion funding as a result of the amendment:

- A twenty-three-year-old woman with cervical cancer was told that Medicaid would pay for a hysterectomy but not for an abortion, which was a prerequisite to appropriate treatment of the disease.

- A woman who had tried to self-abort with a coat hanger was hospitalized with an infection. Medicaid paid for treating the infection but would not pay for an abortion because her pregnancy was not seen as life threatening.

- A woman carrying a twenty-two-week foetus with a fatal heart defect was denied funding for an abortion. ${ }^{81}$

By a 5-4 margin, the 1980 Supreme Court case, Harris $v$ McRae $^{82}$, upheld Federal and State rights to refuse to pay for poor women's abortions, even where medically necessary ${ }^{83}$, such as in the examples illustrated above. ${ }^{84}$ The Court held that a woman's right to choose was not the same as a right to access abortion: "it simply does not follow that a woman's freedom of choice carries with it a constitutional entitlement to the financial resources to avail herself of the full range of protected choices." 85 This case upheld HA and resulted in state campaigns to prohibit state funding of abortions. In the US today, only a small number of states fund abortions in the same way they fund other medical procedures ${ }^{86}$. $^{87}$

HA obstructs low-income and indigent women from accessing abortion services and highlights the partiality of Congress and the Supreme Court to protecting foetal rights at the expense of women's reproductive autonomy, physical health and psychosocial well-being.

In the US six million women of reproductive age are reliant on Medicaid for their healthcare. These women bare the brunt of federal government

\footnotetext{
${ }^{81}$ Ibid 213.

${ }^{82}$ Harris $v$ McRae, 448 US 297 (1980).

${ }^{83}$ At no point during Harris $v$ McRae was the term 'medically necessary' abortion defined.

${ }^{84}$ Harris $v$ McRae, 448, US 297 (1980).

${ }^{85}$ Harris $v$ McRae, 448 US 297 (1980) at 316.

${ }^{86}$ See Appendix A for a break down of state abortion funding.

${ }^{87}$ Alison M Jaggar, 'Regendering the Abortion Debate' in R Solinger (ed) Abortion Wars: A Half Century of Struggle 1950-2000 (1998)339.
} 
prioritisation of childbirth over abortion. ${ }^{88}$ In the absence of federal funding these women are forced to scrape together money to obtain an abortion or continue their pregnancy to term if they are unable to raise the money. Women who manage to find money to fund an abortion do so at great cost to themselves and their families. ${ }^{89}$ Following HA a large number of pregnancies which previously would have been aborted have been carried to term. ${ }^{90}$ Prospective longitudinal research shows unwanted births lead "to mental health problems for mothers, lower emotional quality relationships between mothers and children... increased violence and less leisure-time interaction during childhood" $" 91$ and being born from an unwanted pregnancy is a risk factor for poor mental health in adulthood. ${ }^{92}$

\section{B The Federal Partial Birth Abortion Ban Act (PBABA)}

On November 5 2003, President Bush ${ }^{93}$ signed another domestic legislative initiative, the $P B A B A$, into law..$^{94} P B A B A$ proscribes the use of 'partial birth' abortions. Congress had attempted to pass 'partial birth' abortion bans five times following Roe. President Clinton vetoed 'partial birth' abortion bans in 1995 and 1997 because the bills did not contain a health exception as prescribed in Casey. ${ }^{95}$ Under President Bush, anti-choice legislators found the support necessary to pass their 'partial birth' abortion ban. PBABA allows abortion only to save the life of a pregnant woman. The life exception is limited, only recognizing fatal physical danger to a woman's life and not physical morbidity, mental health or quality of life. $P B A B A$ provides imprisonment up to two years, a fine, or both as punishment for performing

\footnotetext{
${ }^{88}$ Heather Boonstra and Adam Sonfield, Rights Without Access: Revisiting Public Funding of Abortion for Poor Women (2000) 3(2) Guttmacher Institute $<\mathrm{http}: / /$ www.guttmacher.org/pubs/tgr/03/2/gr030208.html $>$ at 18 August 2006.

${ }^{89}$ Ibid.

${ }^{90}$ Ibid.

${ }^{91}$ Henry P David, Zdenek Dytrych and Zdenek Matejcek, 'Born Unwanted: Observations From the Prague Study' (2003) 58(3) American Psychologist 224, 225. ${ }^{92}$ Ibid.

${ }^{93}$ Any reference in this article to President Bush, refers to President George W. Bush

${ }^{94}$ Partial-Birth Abortion Ban Act, Pub L No 108-105, 3, 117 Stat 1201 (to be codified at 18 USC 1531, (2003).

${ }^{95}$ Allisa Schecter, 'Choosing balance: Congressional powers and the Partial Birth Abortion Ban Act of 2003' (2005) 73 (March) Fordham Urban Law Journal 1987.
} 
the proscribed procedure. $P B A B A$ extends civil and criminal liability to a physician who performs an abortion using the proscribed procedure. ${ }^{96}$

$P B A B A$ contradicts the Supreme Court's position on 'partial birth' abortion bans in Stenberg. ${ }^{97} P B A B A$ is the same as the 'partial birth' abortion ban in Stenberg in three main ways:

1. the ban criminalizes abortions throughout pregnancy, although its sponsors claim it only applies to post-viability abortions

2. the ban fails to:

a. exclude the D\&E or suction curettage abortion methods;

b. limit its prohibitions to abortions of 'intact' foetuses; and

c. include definitions of terms "completion of delivery" and "living"

3. the ban also fails to include a health exception. ${ }^{98}$

Despite $P B A B A$ 's sponsors contention that $P B A B A$ is only intended to apply to post-viability abortions, the lead sponsor of the bill, Rep. Steve Chabot, has admitted $P B A B A$ was primarily intended to ban pre-viability abortions. ${ }^{99}$ Similar to Stenberg, the definition of 'partial birth' abortion in $P B A B A$ is wide and vague enough to include both $D \& X$ and $D \& E$ procedures which are the safest and most commonly used form of second trimester abortion. This is despite the sponsors of the bill being supplied with clear instructions from the Supreme Court as to how the statute could be written to exclude D\&E procedures. ${ }^{100}$ The failure to include a health exception is a blatant rejection of established Supreme Court precedents dating back to Casey and Roe. Congress justified its failure to include a health exception by claiming it was not bound to accept the same 'clearly erroneous' standard accepted by the Supreme Court in Stenberg, stating it was entitled to reach its own factual findings. ${ }^{101}$ Congress stated that 'partial birth' abortion is never necessary to

${ }^{96}$ Partial-Birth Abortion Ban Act, Pub L No 108-105, 3, 117 Stat 1201 (to be codified at 18 USC 1531, (2003).

${ }^{97}$ Stenberg $v$ Cahart, 530 US 914 (2000).

${ }^{98}$ Centre For Reproductive Rights, Unconstitutional Assault on the Right to Choose: Federal Abortion Ban Is an Affront to Women and to the U.S. Supreme Court, Centre For Reproductive Rights (December 2003) <http://

www.reproductiverights.org/pdf/pub_bp_uncon_assault.pdf $>$ at 20 July 2006. ${ }^{99}$ Ibid.

${ }^{100}$ Ibid.

101 HOUSE REPORTS: Nos. 108-58 accompanying H.R. 760 (Comm. on the Judiciary) and 108-288 (Comm. of Conference), Vol. 149 (2003),

$<$ http://www.lib.umich.edu/govdocs/text/pl108105.txt $>$ at 28 July 2007. 
preserve the health of a woman. ${ }^{102} P B A B A$ 's sponsors claimed that the Supreme Court must defer to Congress findings that a health exception is not necessary. For the Supreme Court to defer to Congress would be a violation of the principle of separation of powers underlying the US system of government ${ }^{103} \cdot{ }^{104}$ Arguably, PBABA is an undue burden on women exercising their constitutional right to choose to obtain an abortion.

The Californian, New York and Nebraskan Federal district courts have declared $P B A B A$ unconstitutional "citing due process violations, declaring the law unconstitutionally vague, and finding an undue burden on pregnant women seeking abortions." 105 Yet $P B A B A$ continues to proscribe the most common and safest methods of abortion in all other states, eroding women's access to abortion. In 2006 the Supreme Court announced it would review $P B A B A{ }^{106}$

\section{International Reform}

The US anti-choice movement has targeted global access to abortion in addition to domestic access. Restrictions have been imposed in a number of ways. President Bush has sought to deny foreign women safe medically sound abortion. Ernst, Katzive and Smock (2004) believe Bush has done this because:

[W]omen in other countries can't vote in U.S. elections, but the members of the National Right to Life Committee not only vote but also donate to candidates and political action committees. U.S. policy makers can placate a conservative constituency by imposing severe abortion restrictions on women in other countries and, at the same time, turning a blind eye to the impact of those policies." 107

${ }^{102}$ Ibid.

${ }^{103}$ The principle of separation of powers was affirmed most recently by the US Supreme Court in US v Morrison, 529 US 598 (2000).

${ }^{104}$ Centre For Reproductive Rights, above n 98.

105 Schecter, above n 95.; Planned Parenthood Federation of America v Ashcroft, 320 F Supp 2d 957 (ND Cal 2004); National Abortion Federation v Ashcroft, $330 \mathrm{~F}$ Supp 2d 436 (SDNY 2004); Cahart v Ashcroft, 331 F Supp 2d 805 (D Neb 2004).

${ }^{106}$ Centre For Reproductive Rights, First-Ever Federal Ban on Abortion Violates

Women's Rights, Centre For Reproductive Rights (February 2006)

$<$ http://www.reproductiverights.org/pub_fac_pba.html $>$ at 20 July 2006.

${ }^{107}$ Ernst, Katzive and Smock, above n $1 \overline{5}, 785$. 
An analysis of some US foreign policies targeting access to abortion are outlined below:

\section{The United Nations Population Fund (UNFPA)}

UNFPA is the largest multilateral population assistance agency in the world, providing contraception, teen-pregnancy prevention, HIV/AIDS prevention and gynecological services in 142 countries. ${ }^{108}$ UNFPA works in the areas of population and development strategy, advocacy, and reproductive health, including family planning and sexual health. ${ }^{109}$ The US was a driving force behind UNFPA's creation in 1969 and had continued to be a leading supporter of its work until 2002.

In July 2002, the US withdrew financial support of UNFPA, stating that continuing to fund UNFPA would violate the Kemp-Kasten Amendment which prohibits US funds from being directed to "any organisation or program which [sic], as determined by the President of the US, supports or participates in the management of a program of coercive abortion or involuntary sterilization." 110 The US cited UNFPA's resumption of its Chinese program in 1998 as its basis for withdrawing funding. The US claimed UNFPA's presence in China suggested it was complicit in China's coercive population policies including forced sterilisation and abortion. This reason was previously used as the sole justification for the US withholding its contribution to UNFPA during 1986-1992. ${ }^{111}$ The rationale behind the withdrawal of funds between 1986-1992 applied to no other agency receiving US support working in China. Even between 1995 and 1998 when UNFPA did not have a China program, congressional opponents of UNFPA led by Rep Chris Smith agitated for a complete cessation of UNFPA funding. Although a complete cessation was not granted, US UNFPA funding halved

\footnotetext{
${ }^{108}$ United Nations Population Fund, UNFPA Expresses Regret at U.S. Decision Not to Grant it Funding (2002) United Nations Population Fund $<$ http://www.unfpa.org/news/news.cfm?ID=70\&Language=1 > at 17 August 2006.

${ }^{109}$ Kaci Bishop, 'Politics before policy: the Bush administration, international family planning, and foreign policy' (2004) 29(3) (Spring) North Carolina Journal of International Law and Commercial Regulation 521. ${ }^{110}$ Ibid 533.

${ }^{111}$ Ernst, Katzive and Smock, above n 15.
} 
from a peak of $\$ 40$ million in 1995 to $\$ 20$ million in $1998 .{ }^{112}$ With the advent of UNFPA's new four-year program in China the US proceeded to completely cut off funding. This is despite UNFPA's new Chinese program being designed meticulously "to demonstrate the effectiveness of voluntary family planning practices and the value of informed consent." 113

According to UNFPA, the US withdrawal of funding will have severe consequences. In one year alone, the cessation of funding will "be responsible for depriving 870,000 women of effective modern contraception, resulting in turn in 200,000 more abortions, 234,000 unwanted births, 1,200 maternal deaths and more than 22,000 infant deaths." 114

\section{The Helms Amendment}

In 1973, following Roe's legalization of abortion in the US, conservative Senator Jesse Helms sponsored an amendment to the federal Foreign Assistance Act which prohibited federal money being used "for the performance of abortions as a method of family planning or to motivate or coerce any person to practice abortions." ${ }^{, 15}$ Following this amendment, in 1974 the US Agency for International Development (USAID) established its own policy, which was later codified, which prohibits US funding for "information, education, training, or communication programs that seek to promote abortion as a method of family planning." 116

In low-income countries, "USAID is the largest bilateral funder of family planning and reproductive health services." 117 The phrase 'abortion as a method of family planning' was narrowly interpreted by USAID to allow US

\footnotetext{
${ }^{112}$ Susan A Cohen, The US and the United Nations Population Fund: A Rocky Relationship (1999), The Guttmacher Report on Public Policy $<$ http:www.guttmacher.org/pubs/tgt/02/1/gr020101.pdf $>$ at 17 August 2006.

${ }^{113}$ Ibid 2.

${ }^{114}$ Ibid 3 .

${ }^{115}$ Foreign Assistance Act, 22 USC 2151b(f)(1) (2000).

${ }^{116}$ USAID, Technical Areas (2005) USAID

$<$ http:/www.usaid.gov/our_work/global_health/mch/mh/techareas/pacfaqs.html $>$ at 1 October 2006.

${ }^{117}$ The Centre for Reproductive Rights, Breaking the Silence: The Global Gag Rule's Impact on Unsafe Abortion, The Centre for Reproductive Rights (2003) $<$ http://www.reproductiverights.org/pub_bo_ggr.html $>$ at 17 July 2006, 5.
} 
abortion funding only to save the life of the woman or in cases of incest and rape. $^{118}$

This restriction on USAID has eroded women's access to abortion services around the world by cutting off funding to abortion providing foreign NGOs. Following these amendments, abortions could only be carried out using nonUSAID funding.

\section{The Global Gag Rule (GGR)}

On January 22 2001, President Bush extended the restriction of USAID funding by re-imposing the GGR ("Mexico City Policy"). GGR reinstates a far more restrictive version of the Mexico City Policy implemented under the Reagan administration in 1984, and rescinded by President Clinton in 1993. ${ }^{119}$ GGR goes beyond restricting NGOs' use of USAID money to fund abortion by "restricting foreign NGOs who receive UASAID family planning assistance from using their own, non-US funds to:

- Provide safe abortion services to the extent that they are legal (including where a woman's health is harmed by the pregnancy);

- Impart accurate medical counselling about, or referrals for, abortion;

- Petition their own governments to liberalize restrictive abortion laws;

- Advocate against attempts to make abortion laws even more restrictive; and

- Engage in public information initiatives and similar educational measure to ensure that abortions are safe and accessible to the full extent that the law allows." 120

To guarantee USAID funding, foreign NGOs must comply with the above restrictions. In 2003 President Bush extended GGR to all US State

\footnotetext{
${ }^{118}$ Ernst, Katzive and Smock, above n 15.

${ }^{119}$ Patty Skuster, Advocacy in Whispers: The Impact of the USAID Global Gag Rule Upon Free Speech and Free Association in the Context of Abortion Law Reform in Three East African Countries (2004) Centre for Reproductive Rights $<$ http:www.reproductiverights.org/pub_articles.html $>$ at 17 August 2006.

120 The Centre for Reproductive Rights, above n 117, 7.
} 
Departments providing voluntary population planning assistance. ${ }^{121}$ GGR impacts foreign NGOs in nearly sixty countries. ${ }^{122}$

The US constitution protects freedom of $\operatorname{speech}^{123}$, yet contradictorily the US is curtailing free speech in foreign countries. If GGR were applied to US based NGOs it would be unconstitutional. GGR infringes basic democratic rights such as the right to free speech and association and places draconian restrictions on the basic democratic rights of citizens around the world. ${ }^{124}$ International outrage followed the implementation of the GGR. International Governments protested that GGR was "not only detrimental to women's health and lives, but also an affront to international human rights standards protecting freedom of speech and the right of citizens to participate in their own democratic political processes." 125 On March 19 2001, a petition condemning GGR was released. Signed by 233 politicians from twenty different countries, the petition received the greatest number of signatures of any petition of its kind. ${ }^{126}$

By denying funding to family planning services in under served areas, GGR increases the number of unintended pregnancies and unsafe abortions and undermines the health of women and their families. It does this by decreasing women's access to reproductive services to prevent pregnancy, sexually transmitted infections (STIs) and HIV/AIDS. ${ }^{127}$ GGR exacerbates the global epidemic of unsafe abortions by making safe abortions and contraception inaccessible. Although unsafe abortion is one of the most easily preventable causes of maternal mortality and morbidity ${ }^{128}$, it remains the leading cause of pregnancy related deaths in countries where abortion is inaccessible, unavailable or illegal. ${ }^{129}$

${ }^{121}$ Ibid 7.

${ }^{122}$ Ibid.

${ }^{123}$ The First Amendment of the United States Constitution protects freedom of speech.

${ }^{124}$ The Centre for Reproductive Rights, European Perspectives on the Global Gag

Rule The Centre for Reproductive Rights

$<$ http:www.reproductiverights.org/pub_articles.html> at 17 August 2006.

${ }^{125}$ Ibid 2.

${ }^{126}$ Ibid.

${ }^{127}$ Ibid.

${ }^{128}$ World Health Day: Safe Motherhood, Address Unsafe Abortion (1998) World

Health Organisation $<$ http://www.who.int/docstore/world-healthday/en/pages1998/whd98_10.html> at 17 August 2006.

${ }^{129}$ The Centre for Reproductive Rights, above $\mathrm{n} 117$. 
NGOs which previously advocated for women's reproductive rights have been effectively silenced by GGR. Because funds may be arbitrarily withdrawn simply due to a perception that an organisation is speaking about abortion, the topic of unsafe abortion has disappeared from NGO and political discussion amidst fears funding will be revoked. Instead, countries dependent on US funding now have a lopsided abortion narrative which fails to canvass the problems of unsafe abortion or advocate for the legalisation and accessibility of abortion. Consistent with the underlying anti-choice agenda, GGR does not prevent organisations advocating for the criminalisation and banning of abortion.

In Kenya, NGOs that were once vocal supporters of comprehensive reproductive health care for women now abstain from debates on reforming the country's restrictive abortion law.... In Ethiopia, where one of the largest NGOs lost US family planning assistance for refusing to be gagged, a climate of fear has pervaded advocacy circles and curbed free speech. ${ }^{130}$

\section{$4 \quad$ Human Rights}

The US government has been pushing their anti-choice, anti-contraception, abstinence only agenda at a number of international human rights forums in recent years. In 2002 at the UN's first Special Session on Children convened by the UN General Assembly to address children's education, health, HIV/AIDs, abuse, exploitation and protection from violence, the US continued its refusal to ratify the UN Convention on the Rights of the Child. The US pushed for the adoption of an 'abstinence only' before marriage policy and wanted language regarding 'reproductive health services and education' removed claiming it implied access to abortion. ${ }^{131}$ The US also objected to the Session's support of sex education for adolescent girls "which it interpreted to mean the provision of contraception, without the consent of parents." 132 The majority of countries did not agree with the US government's values and logic, and the US requests were eventually defeated.

\footnotetext{
${ }^{130}$ Ibid 10.

${ }^{131}$ Ernst, Katzive and Smock, above n 15.

${ }_{132}$ Caroline Overington, 'Australia backs UN on child rights', The Age (Melbourne), 8 May 2002.

${ }^{133}$ Kaci Bishop, 'Politics before policy: the Bush administration, international family planning, and foreign policy' (2004) 29(3) (Spring) North Carolina Journal of International Law and Commercial Regulation 521.
} 
At the Fifth Asian and Pacific Population Conference in Bangkok, Thailand, in December 2002 the US delegation refused to reaffirm provisions from agreements on reproductive health and family planning such as the International Conference on Population and Development (ICPD) adopted in 1994 by 179 countries. The US delegation stated they did not support the concept of "reproductive rights" as it promoted abortion. ${ }^{134}$ The US was solitary in its objection to the ICPD language. Every other delegation disagreed with the US policy. ${ }^{135}$

US opposition to international human rights, and in particular reproductive rights, clearly broadcasts its anti-choice agenda to the rest of the world. The US administration seems unconcerned that it has little support from other United Nations members, and indifferent about the adverse consequences of its agenda on the life expectancy and quality of life for women and their families.

\section{The Bush Government's Domestic Policy}

The Bush government has used a number of domestic initiatives to further erode abortion rights. It has bestowed numerous rights on foetuses, embryos and fertilised eggs under the State Children's Health Insurance Scheme $(\mathrm{SCHIP})^{136}$. The scheme establishes embryos or foetuses as separate beneficiaries of government programs from conception. President Bush has also advised the Advisory Commission on Human Research Protection that embryos should be considered 'human research subjects'. ${ }^{137}$ The Unborn Victims of Violence Act ${ }^{138}$ creates a separate offence for the bodily injury or death of a foetus or embryo during the commission of a federal crime. The bill treats foetuses, embryos, blastocysts, or zygotes as persons. ${ }^{139}$ This is despite Roe's ruling that the word 'person' used in the Fourth Amendment does not include the unborn. ${ }^{140}$

\footnotetext{
${ }^{134}$ Ernst, Katzive and Smock, above n 15.

${ }^{135}$ Bishop, above n 133, 541.

${ }^{136}$ State Children's Health Insurance Program; Eligibility for Prenatal Care for Unborn Children, 67 Fed. Reg. 9,936 (Mar. 5, 2002) (to be codified at 42 C.F.R. pt. 457); 42 U.S.C. $\$ 1397(\mathrm{jj})(\mathrm{a}),(2000)$.

${ }^{137}$ Ernst, Katzive and Smock, above n 15.

${ }^{138}$ Unborn Victims of Violence Act of 2003, S.146, $108^{\text {th }}$ Cong. (2003).

${ }^{139}$ Ibid.

${ }^{140}$ Ernst, Katzive and Smock, above n 15.
} 
To further restrict teenagers' access to abortion services, the Bush government has implemented The Child Custody Protection Act (CCPA) ${ }^{141}$. CCPA criminalizes a person knowingly transporting a minor who has not complied with the parental consent laws of her state across state lines to obtain an abortion. The bill was passed by the US senate on the $25^{\text {th }}$ of July 2006 and prevents people including doctors, family members other than parents, or clergy from helping minors cross state lines to avoid parental involvement laws. ${ }^{142}$ The senate voted 51 to 48 to reject an amendment to use federal money to educate teenagers about abstinence and contraception, highlighting that the US' priority is to eradicate abortion, rather than effect a decline in unwanted pregnancies. ${ }^{143}$

\section{IMPLICATIONS OF THE EROSION OF ROE: US STATE LEGISLATIVE AND REGULATORY RESTRICTIONS ON ABORTION}

Among the barriers that are less tangible, and therefore more difficult to quantify, are women's lack of accurate information about the legality of abortion and about where and how to obtain abortion care, misinformation about abortion, intimidation by protestors, state-required waiting periods and mandated counseling topics that may not be relevant to a woman's personal situation. ${ }^{144}$

Since Roe legalised abortion in 1973, numerous state governments have restricted access to abortion. State legislatures have waged anti-choice campaigns by imposing legislative and regulatory restrictions on abortion. Following Casey, states found themselves with broader scope for legislating to limit access to abortion. Under the anti-choice Bush government and with the possibility of new Bush anti-choice Supreme Court appointments, state legislatures have been implementing increasingly restrictive anti-choice legislation and regulations. In fact, more than 800 state bills limiting abortion rights have been introduced in the last four years. In Utah, a law was proposed which would have sentenced women who had obtained an abortion to the

${ }^{141}$ Child Custody Protection Act, S. 851, 108th Cong. § 2431 (2003).

142 Ibid.

${ }^{143}$ Charles Babington, 'Interstate Abortion Bill Clears Senate', Washington Post

(Washington), 26 July 2006.

${ }^{144}$ Stenley K Henshaw and Lawrence B Finer, 'The Accessibility of Abortion Services in the US, 2001' (2003) 35(1) Perspectives on Sexual and Reproductive Health 16. 
death penalty. The bill was defeated. ${ }^{145}$ Outlined below are some state restrictions on access to abortion. ${ }^{146}$

\section{A Parental Consent and Notification Laws}

Parental consent laws were first considered by the Supreme Court in Danforth ${ }^{147}$ in 1976. The statute in question required an unmarried minor to obtain one parent's consent before she could undergo an abortion. The Court rejected the statute as it allowed third parties such as parents to make arbitrary decisions to block their daughters' access to abortions. ${ }^{148}$ However, the concurring opinion of Justice Stewart stated that only the parent's absolute veto was unconstitutional. If a bypass mechanism had been present which allowed an exception for mature minors and situations in the minor's best interests, the statute would have been valid. ${ }^{149}$

In 1979, Bellotti v Baird ${ }^{150}$ provided that a parental consent statute could be constitutional if it contained a judicial bypass, where authorisation for an abortion could be obtained. The Court held an alternative procedure should be utilised where the minor could demonstrate she is informed and mature enough to make her own decision, or where she is not informed or mature enough, the decision is in her best interest. ${ }^{151}$ The decision would be in her best interests where informing her parents could lead to emotional, physical or sexual abuse. The court also established that the alternative procedure must be confidential and be able to be scheduled quickly with an expedited appeals process. ${ }^{152}$ Bellotti established the benchmark for constitutionality of judicial bypass provisions in parental consent statutes.

Ohio's parental notification law was upheld by the Supreme Court in Ohio v Akron Center for Reproductive Health ${ }^{153}$ in 1990. The law required a parent

${ }^{145}$ Claudine Holt, Abortion: A Woman's Right to Choose: The Case for Law Repeal (DATE) Democratic Socialist Party $<$ http://www.dsp.org.au/dsp/abortion.htm $>$ at 15 July 2006.

${ }^{146}$ Please see Appendix A for a state-by-state break down of some of the state regulations.

${ }^{147}$ Planned Parenthood of Missouri v Danforth, 428 US 85 (1976).

${ }^{148}$ Ibid at 74 .

${ }^{149}$ Ibid at 91.

${ }^{150}$ Bellotti v Baird, 433 US 622 (1979).

${ }^{151}$ Ibid at $643-644$.

${ }^{152}$ Ibid at 644 .

${ }^{153}$ Ohio v Akron Center For Reproductive Health, 497 US 502 (1990). 
of a minor to be notified prior to an abortion. The law also provided a 'judicial by-pass' provision allowing a minor to have an abortion if it were in her best interests. ${ }^{154}$

Pro-choice supporters were hopeful that the Supreme Court would disable states' rights to impose parental consent or notification laws by striking down New Hampshire's parental notification law in Ayotte ${ }^{155}$. However, the Court avoided the issue, leaving the question of parental consent and notification laws open. In 2006 there are twenty-six states with parental consent requirements and nineteen states with parental notification requirements ${ }^{156} \cdot{ }^{157}$

\section{B Mandatory Counselling}

Another legislative initiative utilised by numerous states has been mandatory abortion counselling. 'Counsellors' are required to provide pregnant women with state mandated information which promotes childbirth over abortion and often is medically inaccurate. ${ }^{158}$ Without this 'counselling' women cannot give their 'informed consent' to an abortion. Although this form of legislation uses the term 'informed consent', this mandatory counselling distorts the concept of informed consent which normally requires that patients are supplied with accurate medical information about the medical procedure they are undergoing. In contrast, the mandatory counselling requirements are scare and delay tactics imposed by states on women to dissuade and obstruct women having abortions.

\section{Waiting Periods}

In the 1983 Supreme Court case, Akron v Akron Centre for Reproductive Health $^{159}$, the Supreme Court struck down a state statute containing provisions which required 'informed consent' and a 24-hour waiting period after 'consent'. The 24-hour waiting period meant women would have to make two

\footnotetext{
154 Ibid.

${ }^{155}$ Ayotte v New Hampshire, $126 \mathrm{~S} \mathrm{Ct} 961$ (2005).

156 See Appendix A for details.

${ }^{157}$ Andrew R Willis, 'Note: The emergency exception in parental involvement laws and the necessity of post-emergency notification' (2006) 4 (Winter) Ave Maria Law Review 171.

${ }^{158}$ Ernst, Katzive and Smock, above n 15.

${ }^{159}$ Akron v Akron Centre for Reproductive Health (Akron 1), 462 US 416 (1983).
} 
trips to the abortion provider. The Court held the consent provision 'unreasonable' because its aim was to discourage a woman from obtaining an abortion rather than to promote the state's legitimate interest in the health of the woman. The Court also struck down the 24-hour waiting period because it increased the cost of accessing an abortion due to increased travel times particularly for those living a long distance from abortion providers, and because it increased exposure to anti-abortion harassment. ${ }^{160}$

Following Casey, these forms of state regulation are now valid, because although they are extremely burdensome, they are not 'substantial' obstacles and thus not an 'undue burden'. The majority upheld a 24-hour waiting period in Casey because it would ensure a women's decision was "thoughtful and informed." 161 Women apparently could not be trusted to make their own decision and were given time to change their minds. The practical reality of waiting periods for abortions is an increase in later stage abortions, increased cost, decreased access to abortion and increased distress and harm to women's health, well-being and self determination.

\section{Clinic Protestors}

To decrease women's access to abortion, some anti-choice groups picket outside abortion providers, harassing and intimidating clinic staff, forcing women and their families to run a gauntlet of intimidation and obstruction to access abortion services. In 1994 the Freedom of Access to Clinic Entrances Act 1994 (US) was passed into federal law allowing buffer or bubble zones to be established around abortion providing clinics. Section 636 "prohibits physically obstructing access to clinics, damaging clinic property, injuring or intimidating patients or staff. Throughout the US different sorts of buffer or bubble zones exist, in the form of ordinances, statutes and injunctions."162 Approximately $25 \%$ of abortion providing clinics are protected by bubble zones. ${ }^{163}$ Despite this progress, $75 \%$ of clinics remain unprotected and

\footnotetext{
${ }^{160}$ Whitman, above n 55.

${ }^{161}$ Planned Parenthood of Southeastern Pennsylvania v Casey, 505 US 833 (1992) at 872.

${ }^{162}$ Rebecca Elizabeth Dean and Susie Allanson, 'Abortion in Australia: Access versus protest' (2004) 11(4) Journal of Law and Medicine 510, 513.

${ }^{163}$ Prochoice Action Network, The Buffer Zone has Become Law! Planned Parenthood League of Massachusetts <http://www.pplm.org/Action/bills/buf_zone/html $>$ at 27 August 2002.
} 
exposed to anti-choice intimidation tactics, abrading women's access to abortion and jeopardising women's health and safety.

\section{E Crisis Pregnancy Centres (CPCs)}

Since 2001, the US federal government has provided over $\$ 30$ million in federal funding to CPCs. An additional $\$ 150$ million has been provided to CPCs as 'capacity building' grants. ${ }^{164}$ With an outward appearance of prochoice medical clinics, CPCs are run by anti-choice organisations. CPCs' goal is to persuade women to continue their pregnancy to term, no matter the consequences. Women access such clinics believing they are the client, but in fact, the embryo or foetus is the CPCs client. ${ }^{165}$ CPCs use shaming, misinformation and inappropriate referral and advice to achieve their goal as outlined below. Currently there are approximately 4,000 CPCs in the US compared with only 2,000 abortion-providing clinics. ${ }^{166}$

CPCs aim to attract what they call 'abortion minded women' by portraying CPC services as pro-choice. They adopt names similar to those of abortion providers in the area; locate CPCs close to abortion providers to trick women into making a CPC appointment; target low-income and young women with the offer of free pregnancy tests; and locate themselves close to universities and colleges; and run advertisements in school newspapers. ${ }^{167}$

CPCs use a number of fear, delay and harassment tactics to prevent women obtaining abortions once they have attended the clinics. "Counsellors" make unfounded links between abortion and breast cancer, increased risks of

\footnotetext{
${ }^{164}$ US House of Representatives Committee on Government Reform - Minority Staff Special Investigations Division, False and Misleading Health Information Provided by Federally Funded Pregnancy Resource Centres, (2006) $<$ http://reform.democrats.house.gov/Documents/20060717101140-30092.pdf $>$ at 20 July 2007.

${ }^{165}$ Susie Allanson, Submission To: Inquiry Into Transparent Advertising And Notification of Pregnancy Counselling Services Bill 2005, Fertility Control Clinic (2006)

$<$ http://www.aph.gov.au/SENATE/COMMITTEE/CLAC_CTTE/pregnancy_counsell ing/submissions/sub02.pdf > at 20 July 2007.

${ }^{166}$ National Abortion Federation, Crisis Pregnancy Centers: An Affront to Choice, National Abortion Federation (2006).

${ }^{167}$ Ibid.
} 
infertility and negative mental health effects ${ }^{168}$ and force women to watch graphic videos depicting medically inaccurate anti-choice propaganda containing footage of dismembered foetuses. ${ }^{169}$ Women have been told their pregnancy test is negative in the hope they will not realise it is positive until it is too late for them to obtain an abortion. CPCs have called women at their workplaces and homes urging them not to have an abortion. ${ }^{170}$

CPCs are another anti-choice strategy to obstruct abortion access within the US. With CPCs outnumbering pro-choice abortion providers two to one, and with their federal funding, CPCs are extremely effective. Pregnant women are forced to negotiate a minefield of non-transparent health services in the hope of finding a pro-choice clinic providing accurate health information and options. Although CPCs present a substantial obstacle to women's access to abortion services, under Casey they are legal because they do not present an 'undue burden' to women's access to abortion.

\section{F Prohibitions on Public Sector Involvement in Abortions}

While CPCs are being handed millions of dollars in federal funding, numerous states have prohibited public facilities and publicly funded facilities

\footnotetext{
${ }^{168}$ Well executed and designed studies have shown that there is little if not no risk of abortion leading to psychological illness, fertility related problems or cancer: Heather D Boonstra, Rachel Benson Gold and Lawrence B Finer, Abortion in Women's Lives (2006). Vacuum aspirated abortions carried out in the first trimester pose virtually no long term fertility related problems: HK Atrash and CJR Hogue, 'The effect of pregnancy termination of future reproduction' (1990) 4(2) Bailliere's Clinical Obstetrics and Gynecology 391. Studies have found abortion is not associated with an increased risk of breast cancer: Collaborative Group on Hormonal Factors in Breast Cancer, 'Breast Cancer and Abortion: Collaborative Reanalysis of Data From 53 Epidemiological Studies, Including 83,000 Women With Breast Cancer From 16 Countries' (2004) 363(9414) Lancet 1007. The mental health of women who have had an abortion is no different from that of women who have carried their pregnancy to term: AC Gilchrist, 'Termination of pregnancy and psychiatric morbidity' (1995) 167 (2) British Journal of Psychiatry 243.

${ }^{169}$ US House of Representatives Committee on Government Reform - Minority Staff Special Investigations Division, False and Misleading Health Information Provided by Federally Funded Pregnancy Resource Centres, (2006) $<\mathrm{http}: / /$ reform.democrats.house.gov/Documents/20060717101140-30092.pdf $>$ at 20 July 2007.

${ }^{170}$ National Abortion Federation, above n 166.
} 
from performing abortions ${ }^{171} .^{172}$ Harris $v$ MacRae ${ }^{173}$ gave US states permission to prohibit abortions being carried out in public facilities or publicly funded facilities. ${ }^{174}$ In 1991 the Supreme Court allowed states to further restrict the use of public funds in relation to abortion by barring doctors from conducting abortion counselling where the doctor was part of any program receiving federal funds, ${ }^{175}$ since "the speech was seen as essentially governmental in nature and therefore could be proscribed by states." 176 State prohibition of public sector involvement in abortion: decreases the number of abortion providers; decreases the number of future abortion providers because of limited training opportunities; diminishes women's ability to find information regarding their reproductive options; and ultimately erodes access to abortion.

\section{G Targeted Regulation of Abortion Providers (TRAP)}

TRAP is another method anti-choice groups have used to undermine women's access to abortion services. TRAP regulations enforce burdensome requirements on abortion providers far more severe than those imposed on other medical practices. ${ }^{177}$ TRAP laws aim to force abortion providers out of business through serious disincentives and impractical requirements. They subject "physicians who provide abortions to criminal and civil penalties, exposing them to harassment, and intruding significantly into their practice of medicine." 178 TRAP requirements increase the cost of obtaining abortions by forcing abortion providers to comply with often confusing requirements which significantly increase the cost of providing an abortion. The effect of TRAP laws is various, some require compliance with minimal licensing

\footnotetext{
${ }^{171}$ Please see Appendix A for a state-by-state public abortion funding break down.

${ }^{172}$ Leighton, above $\mathrm{n} 58$.

${ }^{173}$ Harris v McRae, 448 US 297 (1980).

${ }^{174}$ Ibid.

${ }^{175}$ Rust $v$ Sullivan, 500 US 173 (1991).

${ }^{176}$ Leighton, above n 58, 50.

177 eg. ALA ADMIN CODE r. 420-5-1-.03(1)(f); ALA CODE § 22-21-33 (Enacted 1949; Last Amended 2001); ALA CODE § 26-23A-6 (Enacted 2002); ALASKA STAT $\S 08.64 .105$ (Enacted 1970); ALASKA ADMIN CODE TIT. 7, § 12.370; GA COMP R \& REGS r. 290-5-33-.08(1); IND CODE ANN § 16-21-2-2.5 (Enacted 2005).

FURTHER GUIDANCE IS REQUIRED TO THE CITATION OF THESE RESOURCES

${ }^{178}$ Centre For Reproductive Rights, Targeted Regulation of Abortion Providers (TRAP): Avoiding the TRAP (2004) Centre For Reproductive Rights $<$ www.reproductiverights.org/pdf/pub_bp_avoidingthetrap.pdf> at 20 July 2006.
} 
provisions, however, others "contain detailed and sometimes confusing and expensive structural, staffing, patient testing and other requirements."

\section{H Abortion Service Providers}

Ninety-two percent of non-metropolitan areas have no abortion provider and $25 \%$ of woman travel over 50 miles to obtain an abortion. ${ }^{180}$ This shortage of abortion providers, coupled with waiting periods, makes abortion expensive and often inaccessible to US women.

Despite abortion being the most commonly performed obstetric medical procedure, medical students are not trained in performing abortions, ${ }^{181}$ and States which utilise TRAP laws provide a clear disincentive for medical students to become abortion practitioners. Combined with the stigma attached to providing abortions, this leaves very little incentive for doctors to become abortion providers. Based on this trend, it is likely that abortion services, and therefore their accessibility, will continue to dwindle.

\section{Abortion Bans}

In 2004, Michigan enacted a total ban on abortion. ${ }^{182}$ However, this law has been subject to a legal challenge and may be overturned as long as Roe remains in force. ${ }^{183}$

Early this year, South Dakota set the stage for a Supreme Court challenge to Roe by legislating to ban abortion. ${ }^{184}$ Governor Mike Rounds, who signed the bill after it was passed by the senate in a 32-12 vote, acknowledged that the

${ }^{179}$ Centre For Reproductive Rights, Law and Regulations Affecting Medical Abortion, Centre For Reproductive Rights (2003)

$<\mathrm{http}: / /$ www.reproductiverights.org/pub_fac_medabor2.html $>$ at 20 July 2006.

${ }^{180}$ Fried, above n 80.

${ }^{181}$ Ibid.

${ }^{182}$ Legal Birth Definition Act, MCL 333.1081 et seq, (2004). FURTHER GUIDANCE IS REQUIRED FOR THE CITATION OF THIS RESOURCE

${ }^{183}$ Erica Smock, What if Roe Fell? The State-by-state Consequences of Overturning Roe $v$ Wade, Centre For Reproductive Rights (2004)

$<\mathrm{http}: / /$ www.reproductiverights.org/pub_bo_whatifroefell.html $>$ at 17 August 2006.

${ }^{184}$ South Dakota Women's Health and Human Life Protection Act HB 1215 (2006). 
law was intended as a direct challenge to Roe. ${ }^{185}$ The bill declares that life begins at conception and makes it a felony for doctors to perform any abortion, except to save the life of a pregnant woman. ${ }^{186}$ The bill includes no exception for a woman's health, rape or incest ${ }^{187}$. Any doctor found guilty of breaking the law faces a maximum of five years imprisonment.

Even before this abortion ban was passed, South Dakota was already one of the most difficult states for accessing abortion. South Dakota has mandatory 24-hour waiting periods, mandatory counselling, and parental consent and notification procedures for minors. Planned Parenthood in Sioux Falls is the only abortion provider in South Dakota. Four doctors are flown in from Minnesota on a rotating basis to provide the procedure one day a week because no South Dakotan doctors will perform the procedure due to stigma and threats. Eight hundred abortions per year are carried out in South Dakota. ${ }^{188}$

Ohio, Kentucky, Indiana and Tennessee have introduced similar legislation. ${ }^{189}$ A Supreme Court challenge to one of these abortion bans is likely to determine the fate of Roe.

\section{The FUtURE Of ACCESS tO ABORTION IN THE US}

\section{A The New Supreme Court}

Chief Justice John Roberts Jr and Justice Samuel Alito are the two most recent US Supreme Court ${ }^{190}$ appointments under the Bush administration.

\footnotetext{
${ }^{185}$ John Holusha, 'South Dakota Governor Signs Abortion Ban', The New York Times (New York), 6 March 2006.

${ }^{186}$ South Dakota Women's Health and Human Life Protection Act HB 1215 (2006).

${ }^{187}$ Casey requires abortion statutes to contain a health exception.

${ }^{188}$ Evelyn Nieves, "SD Abortion Bill Takes Aim at 'Roe", Washington Post (Washington), 23 February 2006.

${ }^{189}$ OHIO REV CODE ANN $\S \S 2919.151(A)(5), 2305.114,2307.53$ (Enacted 2000); KY REV STAT. ANN §§ 311.595, 311.720, 311.765, 311.990 (Enacted 1998); IND CODE ANN §§16-18-2-267.5 (Enacted 1997), 16-34-2-1(b) (Original Statute Enacted 1973; Recodified 1993; Relevant Provision Enacted 1997), 16-34-2-7 (Original State Enacted 1973; Recodified 1993; Relevant Provision Enacted 1997); TENN CODE ANN § 39-15-209 (Enacted 1997). FURTHER GUIDANCE IS REQUIRED FOR US RESOURES

${ }^{190}$ The US Supreme Court comprises the Chief Justice of the US and eight Associate Justices. Supreme Court Justices are nominated by the US President and confirmed by
} 
Justice Alito has publicly expressed his anti-abortion stance and replaces Justice Sandra Day O'Connor who supported a woman's right to choose. Justice Roberts has expressed no public view in relation to abortion, however, given his conservative leanings it is possible he may vote against Roe. ${ }^{191}$ Justice Roberts replaced Justice William Rehnquist who had stated he would overturn Roe if given the opportunity. Justices Scalia and Thomas are the two most conservative justices on the bench. They are on record as stating they would overturn Roe if given the chance. They believe the State's right to protect inutero "life" outweighs a woman's right to liberty via bodily autonomy and the right to abortion. Justices Stevens, Souter, Ginsburg and Breyer believe the US constitution protects a woman's right to abortion before viability and where a woman's life or health is endangered after viability. Justice Kennedy's support for Roe has been mixed and it is unclear which way he may vote. ${ }^{192}$

If Kennedy and Roberts choose to vote against Roe, the Supreme Court would have the numbers to overturn Roe. Given President Bush may still have the opportunity to place another justice on the bench, and it is likely President Bush would appoint an anti-choice candidate, the possibility of Roe being overturned is increasing. ${ }^{193}$ However, the newly Democrat controlled US congress may impede President Bush appointing anti-choice candidates.

\section{B What Happens if Roe is Overturned?}

the Senate. They are appointed to their position for life and can only be removed by resignation, or impeachment and subsequent conviction. The Supreme Court currently comprises Justices John G Roberts, John Paul Stevens, Antonin Scalia, Anthony Kennedy, David Souter, Clarence Thomas, Ruth Bader Ginsburg, Stephen Breyer and Samuel Alito.

${ }^{191}$ Nieves, above n 188.

${ }^{192}$ In Webster in 1989, Kennedy argued Roe should be overruled, referring to a State's compelling interest in foetal life from the moment of conception. However, in Casey, Kennedy joined the majority in upholding the key principles of Roe. In 2000 Kennedy dissented in Stenberg, causing numerous pro-choice advocates to believe Kennedy would in fact vote against Roe given the opportunity. In his dissent, Kennedy distanced himself from Roe, refusing to reaffirm the key principles of Roe. Kennedy was also uncharacteristically hostile in his dissent derogatorily referring to pro-choice advocates as 'abortionists': Smock, above n 183.

${ }^{193}$ OnlineNewsHour, South Dakota Abortion Ban (2006) PBS

$<$ http://www.pbs.org/newshour/bb/law/jan-june06/abortion_3-03.html $>$ at 27 July 2006. 
If Roe is overturned by the Supreme Court, abortion will immediately become illegal in all states which have old statutes banning abortion. Women in those states will go from being able to access legal abortion one day, to being unable to access legal abortion the day after. In states where abortion bans were blocked after Roe, but never repealed, legislators could motion for the orders to be vacated and begin enforcing the bans. States which do not have abortion bans on their books, can immediately legislate to ban abortion, if they choose. ${ }^{194}$

According to a study commissioned by The Centre for Reproductive Rights (2004), if Roe fell, women in $21^{195}$ states are likely to lose their right to choose abortion due to abortion bans already on the books or the enactment of new bans. ${ }^{196}$ There are 20 States where abortion rights appear safe due to existing constitutional protection or statutory protections coupled with a friendly legislative environment ${ }^{197}$

US women's access to legal abortion has never been so vulnerable. Many US women do not realize their right to legal abortion could disappear so easily. Many believe the abortion war was won when a woman's constitutional right to abortion was recognized in Roe. Anti-choice groups have been working for decades to get the numbers on the Supreme Court to overturn Roe. This may be the year Roe falls, and American women lose their right to legal abortion.

\section{ABORTION IN AUSTRALIA}

Although the primary focus of this article is the erosion of access to abortion in the US, the following section provides a brief and limited overview of the current status of abortion in Australia. This overview contextualises the lessons Australia can learn from the US situation to protect abortion access. Such lessons may be growing in importance given a number of recent

${ }^{194}$ Smock, above n 183.

195 The 21 states are: "Alabama; Arkansas; Colorado; Delaware; Kentucky; Louisiana; Michigan; Mississippi; Missouri; Nebraska; North Carolina; North Dakota; Ohio; Oklahoma; Rhode Island; South Carolina; South Dakota; Texas; Utah; Virginia; and Wisconsin": Smock, above n 183, 8 .

${ }^{196}$ Ibid.

197 “Alaska; California; Connecticut; Florida; Hawaii; Maine; Maryland; Massachusetts; Minnesota; Montana; Nevada; New Jersey; New Mexico; New York; Oregon; Tennessee; Vermont; Washington; West Virginia; and Wyoming": Smock, above n 183,8 . 
Australian anti-choice legislative initiatives, and indications that anti-choice philosophy has already infiltrated Australian government policy at both state and federal levels.

\section{A Incidence of Abortion}

Chan and Sage (2005) ${ }^{198}$ reported that currently data is unavailable to accurately derive the number of induced abortions in Australia. However, the incidence of abortion in Australia can be estimated by drawing on three data sources: the average number of Medicare funded abortions in Australia between 1995 and 2004 was 75,700; the Australian Institute of Health and Welfare's (AIHW) statistics indicated 52,000 abortions performed in Australian hospitals between 2002-2003; and in South Australia there were approximately 17.2 pregnancy terminations for every 1000 woman aged between $15-44 .{ }^{199}$ Chan \& Sage estimated that 84,460 abortions occurred in Australia in 2003.

\section{B Attitude to Abortion}

A vast majority of Australians support a woman's right to access abortion: in 2003 a survey of 5000 Australians found that $81 \%$ supported a woman's right to choose abortion, 9\% did not support a woman's right to choose, and $10 \%$ were undecided. ${ }^{200}$ Despite this overwhelming support, as discussed below, abortion remains within the criminal statutes of most states and territories, and stigma surrounds the provision and access of abortion. Anti-choice politicians are vocal within both state and federal parliaments leading to a national antichoice abortion narrative inconsistent with the majority of Australians' prochoice views. Over recent years, numerous attempts have been made by antichoice politicians to curtail Australian women's access to abortion. Concurrently, the Australian pro-choice movement has made gains in its campaign to ensure women's access to abortion.

${ }^{198}$ Annabelle Chan and Leonie C Sage, 'Estimating Australia's abortion rates 19852003' (2005) 182(9) The Medical Journal of Australia 447.

${ }^{199}$ Angela Pratt, Amanda Biggs and Luke Buckmaster, How many abortions are there in Australia? A discussion of abortion statistics, their limitations, and options for improved statistical collection (2005).

200 Rachel Gibson, Shaun Wilson, David Denemark and Gabrielle Meagher, The Australian Survey of Social Attitudes, Australian National University: ACSPRI Centre for Social Research (2006). 


\section{The Legal Status of Abortion in Australia}

Although abortion is criminalised in most Australian states and territories, it is generally lawful for mental health, physical health or economic reasons. What constitutes a 'lawful' abortion varies from state to state. ${ }^{201}$ In Victoria, NSW and Queensland, the common law provides that abortion is lawful where a woman's mental or physical health is in danger, inclusive of economic, social or medical reasons. ${ }^{202}$ In South Australia, the Northern Territory and Tasmania, abortion is lawful where the pregnancy poses a physical or mental health risk to the woman or if there is a significant chance the child will be disabled. $^{203}$ In Western Australia, abortion is lawful where the pregnant woman gives informed consent or the continuation of the pregnancy may cause the pregnant woman physical or mental harm. ${ }^{204}$ In 2002 the Australian Capital Territory became the first Australian state or territory to legalise abortion and provide protection against backyard abortions by specifying that only medical practitioners on licensed premises may carry out abortions. ${ }^{205}$ Queensland, New South Wales, Victoria and Tasmania do not limit the gestation at which abortions may be carried out. ${ }^{206}$ In Western Australia, two medical practitioners from a medical panel of six appointed by the Minister must agree that the mother or foetus has a severe medical condition for the abortion beyond 20 weeks gestation to be lawful. ${ }^{207}$ In South Australia an abortion must be carried out within 28 weeks of conception for it to be legal. ${ }^{208}$ In the Northern Territory abortions are lawful up to fourteen weeks gestation on maternal health or foetal disability grounds. Abortion is

${ }^{201}$ Australian Reproductive Health Alliance, The Legal Status of Abortion in Australia (2004) Australian Reproductive Health Alliance

$<\mathrm{http}$ ://www.arha.org.au/factsheets/thelegalstatusofabortioninaustralia.pdf $>$ at 12 September 2006.

${ }^{202}$ Crimes Act 1958 (Vic), ss 65, 66, R v Davidson [1969] VR 667; Crimes Act 1900 (NSW), ss 82, 83 and 84, $R v$ Wald (1971) 3 DCR NSW 25; Queensland Criminal Code 1899 (QLD), ss 224, 225, 226 and 282; $R$ v Bayliss and Cullen (1986) 9 QLR 8.

${ }^{203}$ Criminal Law Consolidation Act 1935 (SA), ss 81(1), 81(2), 82 and 82A; Criminal Code 1983 (NT), s 208B, Medical Services Act 1982 (NT), s 11; Criminal Code Act 1924 (Tas), ss 134, 135 and 164.

${ }^{204}$ Criminal Code 1913 (WA) ss 199, 259; Health Act 1911 (WA) ss 334, 335.

${ }^{205}$ The Medical Practitioners (Maternal Health) Amendment Act 2002 (ACT).

${ }^{206}$ Crimes Act 1958 (Vic), ss 65, 66, $R$ v Davidson [1969] VR 667; Crimes Act 1900 (NSW), ss 82, 83 and 84, $R v$ Wald (1971) 3 DCR NSW 25; Queensland Criminal Code 1899 (QLD), ss 224, 225, 226 and 282; $R$ v Bayliss and Cullen (1986) 9 QLR 8; Criminal Code Act 1924 (Tas), ss 134, 135 and 164.

${ }^{207}$ Health Act 1911 (WA), s 7.

${ }^{208}$ Criminal Law Consolidation Act 1935 (SA), s 82A. 
also lawful up to twenty-three weeks gestation if the doctor believes in good faith it is necessary to prevent grave injury to the pregnant woman's mental or physical health. Abortion is lawful at any stage if the medical practitioner believes in good faith it is necessary to save the pregnant woman's life. ${ }^{209}$

Therefore, although abortion is technically illegal in most Australian states and territories, the common law and statute provide exceptions for "lawful" abortion, and in practice, women generally have relatively unrestricted access to early abortions. Victorian Premier Steve Bracks recently stated he would rather not change abortion law in Victoria, but left room for the possibility of a conscience vote on legalising abortion if Labor were returned to power. ${ }^{210}$ Since the re-election of the Bracks government in 2006, no move has been made to change abortion law in Victoria.

Nonetheless, ambiguity in Australian abortion laws may leave doctors vulnerable to criminal prosecution. ${ }^{211}$ Below, two recent cases in NSW and Victoria highlight abortion providers' vulnerability under criminal laws and medical practice regulations.

\section{$1 \quad$ New South Wales}

In 2006 Dr Suman Sood became the first doctor since 1971 to be prosecuted for procuring an unlawful abortion in NSW. ${ }^{212}$ In 2002, Dr Sood consulted with a 20 -year-old woman who had just found out she was 23 weeks pregnant and who requested an abortion. In preparation for an abortion the next day, Sood inserted a prostaglandin tablet in the patient's vagina and provided two pills to swallow. ${ }^{213}$ At home that night, the woman delivered a foetus which was pronounced dead five hours later. Sood was cleared of a manslaughter charge for the death of the foetus, but was convicted of two charges of unlawfully procuring a miscarriage. ${ }^{214}$

${ }^{209}$ Criminal Code 1983 (NT), s 208B, Medical Services Act 1982 (NT), s 11.

${ }^{210}$ Farrah Tomazin, 'Bracks wants status quo on state abortion stance', The Age (Melbourne), 6 September 2006.

${ }^{211}$ Lachlan de Crespigny and Julian Savulescu, 'Abortion: Time to clarify Australia's confusing laws' (2004) 181(4) The Medical Journal of Australia 201, 203.

${ }^{212} R v$ Sood [2006] NSWSC 1141; Leslie Cannold, Abortion Case Could Set An Ugly Precedent (2005) Reproductive Choice Australia

$<\mathrm{http}$ ://www.reproductivechoiceaustralia.org.au/Media/Abortion_case_could_set_an ugly precedent.pdf $>$ at 19 September 2006.

${ }^{213} R$ v Sood [2006] NSWSC 1141.

${ }^{214}$ Ibid. 
The case prompted medical groups to call for abortion law reform. Australian Medical Association obstetrics and gynaecology spokesman Andrew Pesce said, "doctors who want to practice with good will and in good faith to provide women with a medical service they seek shouldn't feel they could be found guilty of a criminal offence when they do that." ${ }^{215}$ Cannold (2005) believes this case is particularly problematic as it reaffirms:

The regulation of abortion under the Crimes, rather than the Health Act, and by so doing the potential criminality of abortion service providers and their patients. This reassertion of the quasiillicit nature of the procedure will ensure that it continues to be surrounded by secrecy and stigma and, as a result, that women's access to quality information and timely services suffers. ${ }^{216}$

\section{$2 \quad$ Victoria}

A six-year legal saga involving an abortion carried out at the Royal Women's Hospital on a woman who was 32 weeks pregnant, finally concluded in September 2006. ${ }^{217}$ Five Royal Women's Hospital doctors were cleared of unprofessional conduct for an elective abortion carried out after the foetus was diagnosed with dwarfism and the woman became suicidal. ${ }^{218}$ The Medical Board of Victoria dismissed the complaint of medical misconduct as frivolous and vexatious. ${ }^{219}$ Anti-choice Liberal Senator Julian McGauran complained to the Medical Practitioners Board about the case in 2001. It is unclear how Julian McGauran received information about the case. The Medical Board was required to investigate the case and requested the Hospital release the woman's medical records. The Hospital refused to hand over the records contending it was a breach of the patient's privacy. The Hospital

\footnotetext{
215 Ibid.

${ }^{216}$ Leslie Cannold, Abortion case could set an ugly precedent (2005) Reproductive Choice Australia

$<$ http://www.reproductivechoiceaustralia.org.au/Media/Abortion_case_could_set_an_ ugly_precedent.pdf $>$ at 19 September 2006.

${ }^{217}$ Royal Women's Hospital v Medical Practitioners Board of Victoria [2006] VSCA 85.
}

${ }^{218}$ ABC News Online, Melbourne doctors cleared over late-term abortion (2006) ABC <http://www.abc.net.au/news/newsitems/200609/s1741773.htm> at 20 September 2006.

${ }^{219}$ Paul Gerber, 'Late-term abortion: what can be learned from Royal Women's Hospital v Medical Practitioners Board of Victoria' (2007) 186(7) The Medical Journal of Australia 359. 
fought the matter in the Magistrates and Supreme Courts and the Court of Appeal where it was ordered to hand over the records in April 2006. ${ }^{220}$

This case detrimentally affected the lives of the pregnant woman, the doctors and their families. The Australian Medical Association's Victorian president, Mark Yates has since highlighted the need for tighter controls over who can make a complaint to the medical board. The State government is now considering an AMA proposal to allow the board to refuse to investigate a complaint based on the complainant's 'standing'. ${ }^{221}$

One of the doctors involved in the case complained that the case took too long, doctors were fearful of prosecution, and the community suffered because doctors were "no longer prepared to offer abortion in many cases when it's ethical and legal, patients get pushed from pillar to post to get an abortion that is lawful., ${ }^{, 22}$ Hospitals and abortion providers were unsure of their legal position in relation to provision of late-term abortions, and women's access to late-term abortions in Victoria may have been undermined.

\section{Anti-Choice Picketers}

Autralian abortion providing clinics contend with anti-choice picketers attempting to "prevent and discourage the provision of abortion services and women's access to abortion-providing clinics."223 Women, their families, local residents and staff may have to pass a picket line of protesters who harass, intimidate and obstruct clinic entrances in order to access abortion providing services. One such clinic, the Fertility Control Clinic in East Melbourne, has lobbied the federal and state governments, and the local council requesting bubble zone legislation similar to that implemented in the US and Canada. However, thus far its requests have been denied. ${ }^{224}$

The clinic also is investigating the enforcement of council by-laws proscribing public nuisance, intimidation and harassment in public

${ }^{220}$ Royal Women's Hospital v Medical Practitioners Board of Victoria [2006] VSCA 85.

${ }^{221}$ Ewin Hannan, 'Doctors cleared over late abortion' The Australian (Sydney), 16 September 2006.

${ }^{222}$ Optusnet, Abortion case doctor criticises investigation $<$ http://www.abc.net.au/news/stories/2006/09/15/1742338.htm> at 22/07/2007.

${ }^{223}$ Dean andAllanson, above n 162, 511.

${ }^{224}$ Ibid. 
places. These by-laws are utilised by the Melbourne City Council in relation to buskers, and arguably the by-laws are applicable to the actions of anti-choice picketers outside abortion providers. ${ }^{225}$ Local police and residents groups are participating in this endeavor to safeguard women's access to abortion providers. ${ }^{226}$

\section{E $\quad$ RU486}

In February 2006, a cross-party bill was passed by conscience vote to remove the veto power of anti-choice Health Minister, Tony Abbott, over the medical abortion drug, mifepristone, better known as RU486. ${ }^{227}$ RU486 has been available in Europe for decades. The Health Minister was originally given the veto power under a 1996 deal to secure the partial privatisation of Telstra. ${ }^{228}$ The bill brought together four pro-choice female senators from the four major political parties: Democrat leader Lyn Allison, Liberal senator Judith Troeth, National senator Fiona Nash and Labor senator Claire Moore. This bill may eventually give women a choice between early surgical abortion or medical abortion via a pill taken under medical supervision. Former Victorian Premier and pro-choice Emily's List member, Joan Kirner, likened the bill's significance to women's right to equal pay. ${ }^{229}$

\section{F Pregnancy Counselling}

After losing his fight against the RU486 bill, Federal Health Minister, Tony Abbott, turned his focus to pregnancy counselling services. $\mathrm{Mr}$ Abbot proposed funding a pregnancy counselling hotline and providing Medicare rebates for pregnancy counselling. The government's tender process for these counselling services precluded abortion providers from applying, ostensibly to ensure provision of a 'non-directive' service. However, it did not prohibit

\footnotetext{
${ }^{225}$ Activities Local Law 1999 (Vic)

${ }^{226}$ Susie Allanson, 'Personal communication from Dr Susie Allanson, Clinical Psychologist at the Fertility Control Clinic to Rebecca Dean' (25/7/2006).

${ }^{227}$ The Therapeutic Goods Amendment (Repeal of Ministerial Responsibility for Approval of RU486) Act 2006 (Cth).

${ }^{228}$ Carol Nadar, 'United across the trenches', The Age (Melbourne), 9 February 2006.

${ }^{229}$ Misha Schubert, Jewel Topsfield and Carol Nada, 'Abortion pill on its way soon' The Age (Melbourne), 17 February 2006.
} 
anti-choice organisations from tendering for the contract. ${ }^{230}$ The telephone pregnancy counselling service contract worth $\$ 15.5$ million was awarded to McKesson Asia Pacific despite McKesson's plans to subcontract parts of the telephone service to Catholic Church group Centacare and the Caroline Chisholm Society.

The federal government provides $\$ 260,000$ funding annually to anti-choice, Australian Federation of Pregnancy Support Services (AFPSS). AFPSS and two other anti-choice agencies received an additional $\$ 100,000$ government grant in 2005, while pro-choice Family Planning Australia's funding has been continually cut over the last ten years. ${ }^{231}$ Similar to US CPCs, anti-choice counselling organizations advertise their services as all-options pregnancy counselling, but refuse to refer women to abortion clinics, provide women with misinformation regarding the harms of abortion such as infertility, breast cancer and mental illness ${ }^{232}$, and dissuade and delay women from having abortions.

Coined 'false providers' by the National Health and Medical Research Council in 1995, these organisations pervasively advertise their women's pregnancy counselling services, confusing women about which organisations offer genuine non-judgmental pregnancy options counselling. ${ }^{233}$ Because such services are free, they are immune from the consumer protection provisions of the Trade Practices $\mathrm{Act}^{234}$ prohibiting false and misleading advertising. Federal Democrat Senator, Natasha Stott Despoja, responded to this problem by introducing the Transparent Advertising and Notification of Pregnancy Counselling Services Bill $2005^{235}$ which "seeks to prohibit misleading and deceptive advertising and notification of pregnancy counselling services;

${ }^{230}$ Leslie Cannold, 'Let's keep the counsellors honest and true', The Age (Melbourne), 17 April 2006.

${ }^{231}$ Adele Horin, '\$60m could buy a lot of dishonesty', Sydney Morning Herald (Sydney) 25 February 2006.

${ }^{232}$ Please see footnote 168 for details regarding the medical risks of abortion.

${ }^{233}$ The term "false providers" was coined in the: National Health and Medical Research Council, Services for the Termination of Pregnancy in Australia: A review. Draft Consultation Document - September 1995, National Health Advisory Committee (1995). Following anti-choice pressure, the final paper relased by the National Health and Medical Research Council removed the reference: National Health and Research Council, An Information Paper on Termination of Pregnancy in Australia, National Health Advisory Committee (1996).

${ }^{234}$ Trade Practices Act 1974 (Cth).

${ }^{235}$ Transparent Advertising and Notification of Pregnancy Counselling Services Bill 2006 (Cth). 
promote transparency and full choice in the notification and advertising of pregnancy counselling services; improve public health; and minimise the difficulties associated with obtaining advice to deal with unplanned pregnancy." 236 This bill has now evolved into the cross-party Pregnancy Counselling (Truth in advertising) Bill $2006^{237}$ and seeks to "force pregnancy counselling organisations to be up front about whether they do or do not refer for terminations, so women can be clear about what sort of organisations they are contacting." ${ }^{238}$ The bill would essentially make pregnancy counselling services subject to false and misleading advertising laws. If this bill is not passed, and particularly if the government hotline is dependent on anti-choice providers, Australian women face a confusing and harmful path to accessing abortion services.

\section{E Foreign Aid}

Australia has followed the US lead in banning funding of abortion services and abortion training in poor nations. Anti-choice former Federal Independent Senator, Brian Harradine, instigated the Australian ban. ${ }^{239}$ A cross-party group of MPs are campaigning to overturn the ban which could result in saving the lives of 68,000 women in the developing world who die of unsafe abortion annually. ${ }^{240}$ Federal Health Minister Tony Abbott and Federal Foreign Affairs Minister Alexander Downer have both rejected the call to overturn the ban, "the Australian Government does not support the funding of abortion training or services, research trials or activities directly involving abortion."241

Arguably, the ban contravenes Australia's international human rights obligations. In 1983 Australia became a signatory to the International Convention on the Elimination of all Forms of Discrimination Against Women. The treaty has been signed by 184 nations and affirms women's reproductive rights: "its signatories must ensure access to health care services,

${ }^{236}$ Natasha Stott Despoja, 'Making counselling services honest on the abortion option', The Age (Melbourne), 22 February 2006, 21.

${ }^{237}$ Pregnancy Counselling (Truth in advertising) Bill 2006 (Cth).

${ }^{238}$ Natasha Stott Despoja, 'Making counselling services honest on the abortion option', The Age (Melbourne), 22 February 2006, 21.

${ }^{239}$ 'Change law on 'funding abortion abroad", The Age (Melbourne), 10 September 2006.

${ }^{240}$ Misha Schubert, 'Abbott rejects aid for overseas abortion training', The Age (Melbourne), 12 June 2006.

${ }^{241}$ Ibid. 
including those related to family planning." ${ }^{242}$ MPs who support overturning the ban are also calling for Australia to join the Global Safe Abortion Fund. This project was established with a $\$ 7.23 \mathrm{~m}$ donation by the British government in 2006 and aims to replace funds cut by President Bush's 'Global Gag rule'. ${ }^{243}$

\section{CONCLUSION}

Access to safe, legal abortion is vital to ensure the physical and psychosocial health of women and their families. ${ }^{244}$ However, anti-choice groups are well funded in the US, have utilised a multi-faceted approach to erode women's access to abortion, and have positioned anti-choice politicians and judges at all levels of federal and state legislatures and judiciary. Access to safe abortion in both the US and developing countries has been restricted through a combination of Supreme Court decisions, foreign and domestic legislative and regulatory initiatives, anti-choice clinics and picketing. Concurrently antichoice groups have chipped away at the legality of abortion to the point where abortion may soon be illegal in the US. Women have reasonable access to abortion in Australia despite abortion generally being relegated to Criminal Codes rather than Health Acts. However, based on the US situation, it appears that even if abortion is legalised across Australia, women's access to abortion may still be under threat. Awareness of anti-choice tactics used to restrict access to abortion in the US may prevent a similar erosion of abortion rights in Australia.

\section{Postscrip}

On April 18, 2007 the US Supreme Court handed down its decision in Gonzales, Attorney General $v$ Carhart et $a l^{245}$. The case considered the legality of the Federal "partial birth abortion" ban. In a 5-4 decision the court held that the Federal statute was constitutional despite striking down a similar Nebraskan statute ${ }^{246}$ seven years ago in Stenberg $v$ Carhart $^{247}$. The Court distinguished the Federal statute from the Nebraskan statute on the basis that the Federal statute included a different, more precise definition of the

242 'Change law on 'funding abortion abroad", above n 239.

${ }^{243}$ Schubert, above $\mathrm{n} 240$.

${ }^{244}$ Ahman and Shah, above n 3.

${ }^{245}$ Gonzales, Attorney General v Carhart et al., 500 US _ (2007).

${ }^{246}$ NEB REV STAT ANN §§28-328(1), 28-326(9) (Supp. 1999))

${ }^{247}$ Stenberg v Cahart, 530 US 914 (2000). 
prohibited procedure. ${ }^{248}$ The Court rejected arguments that the Act imposed an undue burden on women attempting to access abortion services. ${ }^{249}$

In her dissenting judgement, Ginsburg $\mathrm{J}$ with whom Stevens, Souter and Breyer $\mathrm{J}$ agreed summed up the majority decision in the following way:

Today's decision is alarming. It refuses to take Casey and Stenberg seriously. It tolerates, indeed applauds federal intervention to ban nationwide a procedure found necessary and proper in certain cases by the American College of Obstetricians and Gynecologists (ACOG). It blurs the line, firmly drawn in Casey, between previability and postviability abortions. And, for the first time since Roe, the Court blesses a prohibition with no exception safeguarding a woman's health.

I dissent from the Court's disposition. Retreating from prior rulings that abortion restrictions cannot be imposed absent an exception safeguarding a woman's health, the Court upholds an Act that surely would not survive under the close scrutiny that previously attended state-decreed limitations on a woman's reproductive choices.

Ginsburg cited the majority's admission that 'moral concerns' were at work in prohibitions on abortion, and held that "by allowing such concerns to carry the day and the case, overriding fundamental rights, the Court dishonours our precedent... The Court deprives women of the right to make an autonomous choice, even at the expense of their safety."250

In recognising the implications of the Court's decision in Roe, Ginsburg noted:

Though today's opinion does not go so far as to discard Roe or Casey, the Court, differently composed that it was when we last considered a restrictive abortion regulation, is hardly faithful to our earlier invocations of 'the rule of law' and the 'principles of stare decisis.' Congress imposed a ban despite our clear prior holdings that the State cannot proscribe an abortion procedure when its use is necessary to protect a woman's health....

\footnotetext{
${ }^{248}$ Gonzales, Attorney General v Carhart et al., 500 US _(2007), at 10-11.

${ }^{249}$ Ibid at 16.

${ }^{250}$ Ibid at $15-17$.
} 
Although Congress' findings could not withstand the crucible of trial, the Court defers to the legislative override of our Constitution-based rulings...

The Act, and the Court's defense of it, cannot be understood as anything other than an effort to chip away at a right declared again and again by this Court - and with increasing comprehension of its centrality to women's lives. ${ }^{251}$

As a result of this decision the Federal proscription of Partial Birth Abortion is constitutional. States legislating to prohibit intact dilation and extraction (D\&X) abortions may do so without needing to provide any exception for protecting a woman's health.

${ }^{251}$ Ibid at 24. 